\title{
Genetic diversity of $\beta$-glucuronidase activity among 14 strains of the dominant human gut anaerobe Ruminococcus gnavus
}

\author{
Diane Beaud $^{1}$, Monique Ladiré ${ }^{1}$, Vasco Azevedo ${ }^{2}$, Chantal Bridonneau ${ }^{1}$ and Jamila Anba-Mondoloni ${ }^{1}$ \\ ${ }^{1}$ Institut National de la Recherche Agronomique, Unité d'Ecologie et de Physiologie du Système Digestif, \\ Domaine de Vilvert, Jouy-en-Josas, France. \\ ${ }^{2}$ Universidade Federal de Minas Gerais, Instituto de Ciências Biológicas, Departamento de Biologia Geral, \\ Laboratório de Genética Celular e Molecular, Belo Horizonte, MG, Brazil.
}

\begin{abstract}
Bacterial $\beta$-glucuronidase activity in the gut increases the enterohepatic circulation of toxic compounds and plays a major role in the etiology of colon cancer. Previously, we had found that the gus gene, which codes for $\beta$-glucuronidase in a dominant anaerobic species of the gut microbiota, Ruminococcus gnavus strain E1, is transcribed as part of an operon that includes three ORFs that code for $\beta$-glucoside permeases of the phosphotransferase systems. This genetic organization had never been described. We have now compared $\beta$-glucuronidase activity and the genetic environment of the gus gene in 14 strains of Ruminococcus gnavus.We found that five out of the seven glucuronidase-positive $R$. gnavus strains possessed another glucuronidase gene different from the gus $A$ operon of $R$. gnavus E1. This dominant commensal intestinal species appears to have a high degree of genetic diversity in the genes that control $\beta$-glucuronidase activity.
\end{abstract}

Key words : Ruminococcus gnavus, glucuronidases, digestive microbiota.

Received: June 6, 2005; Accepted: November 11, 2005.

\section{Introduction}

Glucuronidation is a major detoxification process that converts a large number of xenobiotic and endogenous substances into more hydrophilic metabolites (Tephly and Burchell,1990; Gueraud and Paris,1998). Parts of the glucuronides are secreted through the biliary route into the intestine. They are poorly reabsorbed into the bloodstream and are efficiently eliminated from the body, unless they are hydrolyzed by intestinal $\beta$-glucuronidase enzymes. However, most of the $\beta$-glucuronidase activity in the caecum and in the large intestine of rats has been attributed to bacterial enzymes (Rod and Midtvedt, 1977). $\beta$-glucuronidase activity increases the enterohepatic circulation of toxic compounds. Consequently, it plays a major role in the generation and maintenance of toxic and carcinogenic metabolites in the body, which can promote tumor formation at various sites, including the large bowel (McBain and MacFarlane,1998; Arimochi et al.,1999). We previously identified and cloned a new $\beta$-glucuronidase gene, gus, in

Send correspondence to Jamila Anba-Mondoloni. Institut National de la Recherche Agronomique, Unité d'Ecologie et de Physiologie du Système Digestif, Domaine de Vilvert 78352 Jouy-en-Josas, France. E-mail: jamila.anba@jouy.inra.fr. an anaerobic strain of the dominant gut microorganism, Ruminococcus gnavus strain E1 (Beaud et al.,2005). This gus gene was transcribed as part of an operon, including three ORFs, ORF2, ORF3 and ORF5. ORF2 and ORF3 products presented strong similarities with many $\beta$-glucoside permeases of the phosphoenolpyruvate $\beta$-glucoside phosphotransferase systems (PTS), such as BglC in Escherichia coli, BglP in Bacillus subtilis and PTS enzyme II in Bacillus halodurans. ORF5 product presents strong similarities with the amino-terminal domain of Clostridium acetobutylicum $\beta$-glucosidase (bglA). Because of the significance of $\beta$-glucuronidase in numerous physiological and pathological processes, including colon cancer, we compared $\beta$-glucuronidase activity and the genetic environment of the corresponding gene in $13 R$. gnavus strains and the original strain E1, isolated from human gut.

\section{Material and Methods}

\section{Ruminococcus gnavus strains and culture conditions}

The $14 R$. gnavus strains were isolated from 14 donors - (Table 1). These strains were identified at the species level on the basis of the nucleotide sequence of the DNA encoding the 16S RNA (Marcille et al., 2002). The strains 
Table 1 - Strains of Ruminococcus gnavus.

\begin{tabular}{|c|c|c|}
\hline R. gnavus strains & $\begin{array}{l}\text { Origin/ Isolated from human } \\
\text { fecal samples of : }\end{array}$ & Reference or source \\
\hline B53 & adults with chronic pouchitis. & Our collection $^{\mathrm{a}}$ \\
\hline B57 & healthy adults( type strain) & ATCC 29149 \\
\hline B70 & patient with Crohn disease. & Our collection $^{\mathrm{a}}$ \\
\hline B74 & patient with Crohn disease. & Our collection $^{a}$ \\
\hline G25 & healthy children. & Our collection $^{\mathrm{a}}$ \\
\hline E1 & healthy adults. & (Ramare F., 1993) \\
\hline V42 & adults with chronic pouchitis. & Our collection $^{a}$ \\
\hline V50 & adults with chronic pouchitis. & Our collection $^{\mathrm{a}}$ \\
\hline V51 & adults with chronic pouchitis. & Our collection $^{\mathrm{a}}$ \\
\hline V62 & healthy adults. & Our collection $^{\mathrm{a}}$ \\
\hline V66 & adults with chronic pouchitis. & Our collection $^{a}$ \\
\hline V58 & adults with chronic pouchitis. & Our collection $^{a}$ \\
\hline V95 & healthy children & Our collection \\
\hline V99 & healthy children & Our collection \\
\hline
\end{tabular}

a'Unité d' Ecologie et de Physiologie du système digestif, Institut National de la Recherche Agronomique, Jouy en Josas, France. All-R. gnavus strains from our collection were identified by $16 \mathrm{~S}$ rDNA sequencing.

were grown in an anaerobic chamber at $37{ }^{\circ} \mathrm{C}$ in reduced BHI broth (Difco) supplemented with $5 \mathrm{~g} / \mathrm{L}$ of yeast extract (Difco) and $5 \mathrm{mg} / \mathrm{L}$ of haemin (Sigma-Aldrich).

\section{DNA Techniques}

Procedures for DNA manipulations were performed essentially as described in Sambrook et al. (1989). Total cellular DNA were extracted from a $R$. gnavus strains as previously described by Beaud et al. (2005). R. gnavus DNAs were digested with EcoRV according to the manufacturer's specifications. Digested genomic DNA $(10 \mu \mathrm{g})$ was separated by electrophoresis through a $1 \%$ agarose gel (Tebu, Le-Perray-en-Yvelines, France) and transferred by capillary blotting to Hybond- $\mathrm{N}^{* * *}$ nylon membranes (Amersham Biosciences) The blots were hybridized with three different $\left[\alpha_{-}{ }^{32} \mathrm{P}\right] \mathrm{dCTP}-$ labelled PCR products obtained with oligonucleotides complementary to the coding strand of the gus gene (5'-AAATCTGCAAAATTCCA-3' and 5'-TCATTATCCTTATGCAGAAGA-3'), ORF2 (5'CGGTTCTGCTCTGGTAGATG-3' and 5'-CAATGCCG CAAATGCAAATC-3') and ORF3 (5'-CAGCCGACGT CGGAAATGG-3' and 5'-ACTGATATCGTGTATTC TC CTC-3').of strain E1. PCR amplifications were performed on genomic DNA of the 14 strains as template, using a pair of primers specific for gus gene (5'-AAATCTGCAAAA TTCCA-3' and 5'-TCATTATCCTTATGCAGAAGA-3'). PCR reactions were performed in a $50 \mu \mathrm{L}$ volume with TaKaRa Ex Taq polymerase (Takara Shuzo) under the following conditions: $94{ }^{\circ} \mathrm{C}$ for $2 \mathrm{~min} ; 30$ cycles of $94{ }^{\circ} \mathrm{C}$ for $15 \mathrm{~s}, 44^{\circ} \mathrm{C}$ for $30 \mathrm{~s}$, and $72{ }^{\circ} \mathrm{C}$ for $1 \mathrm{~min}$; and a final elongation step at $72{ }^{\circ} \mathrm{C}$ for $7 \mathrm{~min}$.

\section{Enzyme assays}

$\beta$-glucuronidase activity was assessed spectrophotometrically in cell extracts prepared by centrifugation of the cell pellet and disrupting it with $106 \mu \mathrm{m}$ glass beads (Sigma-Aldrich). The enzyme activity was measured as the rate of release of para-nitro-phenol (at $\lambda=400 \mathrm{~nm}$ ) from para-nitro-phenyl- $\beta$-D-glucuronide (PNPG) (Sigma-Aldrich). One unit of activity is defined as $1 \mathrm{nmol}$ of paranitro-phenol formed per min per milligram of total protein. Each value was calculated as the average of at least three independent determinations (Beaud et al., 2005).

\section{Results}

Seven out of $14 R$. gnavus strains possessed $\beta$-glucuronidase activity (Figure 1). PCR amplifications and hybridization experiments showed that two out of the seven glucuronidase-positive strains (B70, E1) possessed the gus operon (Figure 2, Table 2).

Surprisingly, two (B53, V66) out of the seven glucuronidase inactive $R$. gnavus strains possessed a gus operon homolog (Figure 2, Table 2). The five other strains (B57, B74, G25, V62, V95), including $R$. gnavus type strain (B57), lacked both $\beta$-glucuronidase activity and the gus operon homolog. Out of the 14 R. gnavus strains isolated from humans, seven presented $\beta$-glucuronidase activity and four possessed the E1 strain gus operon or a homolog (Table 2).

\section{Discussion}

Out of the seven glucuronidase-positive $R$. gnavus strains, five (V42, V50, V51, V58 and V99) were found to possess a glucuronidase gene quite different from the gus $\mathrm{A}$ operon of $R$. gnavus $\mathrm{E} 1$. In order to be sure that these five $\beta$-glucuronidase strains did not possess a gusA homolog, lower stringency hybridizations were performed under the same conditions. The same results were obtained, so we

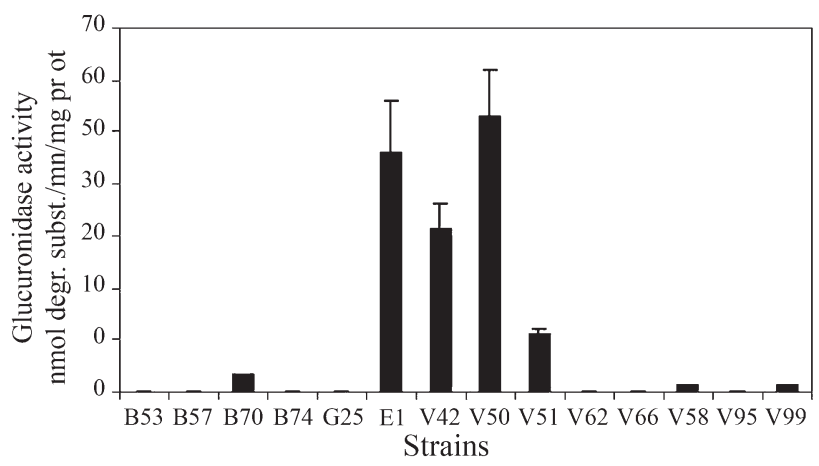

Figure 1 - $\beta$-glucuronidase activity of Ruminococcus gnavus strains, after $24 \mathrm{~h}$ of growth, based on the ability of cell extracts to hydrolyse PNPG. $\beta$-glucuronidase activity was expressed in nmol of degraded substrate/ $\mathrm{min} / \mathrm{mg}$ of total proteins. Each value presented is the average of results from at least three independent experiments. 
Table 2 - Summary of $\beta$-glucuronidase activity, PCR amplifications and hybridizations for each strain. All strains are Ruminococcus gnavus strains, listed in Table1.

\begin{tabular}{|c|c|c|c|c|c|}
\hline \multirow[b]{2}{*}{$\begin{array}{l}\text { R. gnavus } \\
\text { strains }\end{array}$} & \multirow[b]{2}{*}{$\begin{array}{c}\beta \text {-glucuronidase } \\
\text { activity }\end{array}$} & \multirow[b]{2}{*}{ gus PCR } & \multicolumn{3}{|c|}{ Hybridizations (probes used) } \\
\hline & & & Gus & ORF2 & ORF3 \\
\hline B53 & - & + & + & + & - \\
\hline B57 & - & - & - & - & - \\
\hline B70 & + & + & + & + & - \\
\hline B74 & - & - & - & - & - \\
\hline G25 & - & - & - & - & - \\
\hline E1 & + & + & + & + & + \\
\hline V42 & + & - & - & - & - \\
\hline V50 & + & - & - & - & - \\
\hline V51 & + & - & - & - & - \\
\hline V62 & - & - & - & - & - \\
\hline V66 & - & + & + & + & - \\
\hline V58 & + & - & - & - & - \\
\hline V95 & - & - & - & - & - \\
\hline V99 & + & - & - & - & - \\
\hline
\end{tabular}

concluded that these strains have no gus gene homolog. The unexpected observation that a number of $\beta$-glucuronidasenegative $R$. gnavus strains possess gusA and ORF2 homologs raises further questions.Isolates of $E$. coli $\mathrm{O} 157: \mathrm{H} 7$ with nucleotide sequences for the uidA gene had no $\beta$-glucuronidase activity (Feng and Lampel,1994). This gene has a small number of mutations that result in the production of an inactive $\beta$-glucuronidase enzyme, which was still recognized by the anti- $\beta$-glucuronidase antibody. Further experiments, such as DNA sequencing and analysis, would be necessary to elucidate the true distribution of gusA and ORFs homologs in these R. gnavus strains. Her possibility could explain the preshence of gusA homologs without $\beta$-glucuronidase activity in these two strains could be the techniques used to measure the activity. We determined the in vitro $\beta$-glucuronidase activity of individual strains by disrupting a pellet of centrifuged bacterial cultures in media containing sugar but no inducer. The gus gene in $R$. gnavus $\mathrm{E} 1$ was transcribed as part of an operon that included three ORFs, ORF2, ORF3 and ORF5. The ORF2 and ORF3 products presented strong similarities with many $\beta$-glucoside permeases of the phosphoenolpyruvate $\beta$-glucoside phosphotransferase systems (PTS). The structural organization of the gus gene suggests a regulation of $\beta$-glucuronidase activity by catabolite repression, dependent on sugar availability. As no chemically-defined medium was available for $R$. gnavus growth, it was not possible to study catabolite repression in this species. Further experiments with media containing inducers, such as

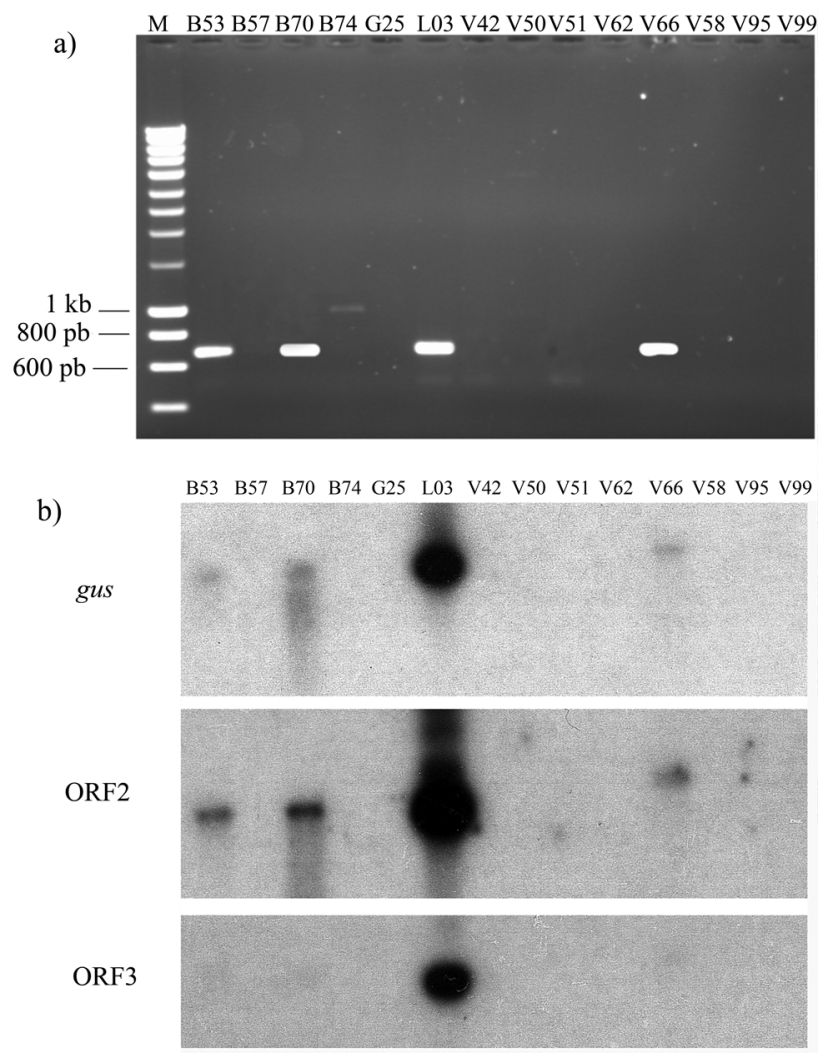

Figure 2 - Genetic analysis of the gus gene environment for strains of Ruminococcus gnavus. A. Agarose gel electrophoresis to analyze the PCR products. Lane $\mathrm{M}$ corresponds to the molecular size marker $1 \mathrm{~kb}$ ladder (Gibco).The other lanes correspond to PCR performed on genomic DNA from $14 R$. gnavus strains. The primers used were specific for the gus gene (685 bp). B. Southern hybridization to identify the genomic fragments carrying the gene gus, ORF2 and ORF3. DNA from $R$. gnavus strains (Table1) was restricted by EcoRV and hybridized with ${ }^{32} \mathrm{P}$-labelled gus, ORF2 and ORF3 probes after electrophoresis. One unique EcoRV fragment of $5 \mathrm{~kb}$ was shown to hybridize to these probes. Previous studies have shown that this fragment comprises these three complete ORFs (Beaud et al., 2005).

methyl-glucuronide or bile extract, should be made with the $\beta$-glucuronidase-negative $R$. gnavus strains.

The true distribution of the functional gusA operon in human gut $R$. gnavus strains and what kind of advantage GusA expression provides to $R$. gnavus have yet to be determined. A number of important natural compounds, including bilirubin and endogenous hormones, are routinely excreted as glucuronide conjugates via bile into the gastrointestinal tract; consequently, $R$. gnavus could use glucuronides for energy production. But the natural substrates of $R$. gnavus are yet unknown. This information may provide clues for dietary control of $\beta$-glucuronidase activity of the intestinal microbiota.

\section{Acknowledgements}

This work was supported by the INRA and the Ilede-France region and is part of the $\mathrm{PhD}$ thesis being prepared by D.B. V.A. is recipient of a grant from the Conse- 
lho Nacional de Desenvolvimento Cientifico e Tecnologico (CNPq, Brazil). We thank G. Corthier, J. Doré, M. Flores, P. Langella and S. Rabot for their advice during the preparation of the manuscript.

\section{References}

Arimochi H, Kataoka K, Kuwahara T, Nakayama H, Misawa N and Ohnishi Y (1999) Effects of beta-glucuronidase-deficient and lycopene-producing Escherichia coli strains on formation of azoxymethane-induced aberrant crypt foci in the rat colon. Biochem Biophys Res Comm 262:322-327.

Beaud D, Tailliez P and Anba-Mondoloni J (2005) Genetic characterization of the beta-glucuronidase enzyme from a human intestinal bacteria, Ruminococcus gnavus. Microbiology 151:2323-2330.

Feng P and Lampel KA (1994) Genetic analysis of uidA expression in enterohaemorrhagic Escherichia coli serotype O157:H7. Microbiology 140:2101-2107.

Gueraud F and Paris A (1998) Glucuronidation: A dual control. Gen Pharmacol 31:683-688.

Marcille F, Gomez A, Joubert P, Ladire M, Veau G, Clara A, Gavini F, Willems A and Fons M (2002) Distribution of genes encoding the trypsin-dependent lantibiotic rumino- coccin A among bacteria isolated from human fecal microbiota. Appl Environ Microbiol 68:3424-31.

McBain AJ and MacFarlane GT (1998) Ecological and physiological studies on large intestinal bacteria in relation to production of hydrolytic and reductive enzymes involved in the formation of genotoxic metabolites. J Med Microbiol 47:407-416.

Ramare F, Nicoli J, Dabard J, Corring T, Ladire M, Gueugneau AM and Raibaud P (1993) Trypsin-dependent production of an antibacterial substance by a human Peptostreptococcus strain in gnotobiotic rats and in vitro. Appl Environ Microbiol 59:2876-2883.

Rod TO and Midtvedt T (1977) Origin of intestinal beta-glucuronidase in germfree, monocontaminated and conventional rats. Acta Pathol Microbiol Scand 85:271-276.

Sambrook J, Fritsch EF and Maniatis T (1989) Molecular Cloning: A Laboratory Manual. 2nd edition. Cold Spring Harbor Laboratory Press, Cold Spring Harbor, New York.

Southern EM (1975) Detection of specific sequences among DNA fragments separated by gel electrophoresis. J Mol Biol 98:503-517.

Tephly TR and Burchell B (1990) UDP-glucuronosyltransferase: A family of detoxifying enzymes. Trends Pharmacol Sci 11:276-279.

Associate Editor: Sérgio Olavo Pinto da Costa 